\title{
AN OVERVIEW OF GOVERNANCE AND ACCOUNTABILITY OF TAHFIZ INSTITUTIONS IN MALAYSIAN: RELIGIOUS COUNCILS PERSPECTIVE
}

\author{
Hamidah Bani*1, Mohd Yassir Jaaffar ${ }^{1}$, Maheran Katan², Abd Halim Mohd Noor ${ }^{3}$ \\ Faculty of Accountancy, Universiti Teknologi MARA Melaka ${ }^{1}$,Faculty of Business \& Management, \\ Universiti Teknologi MARA Melaka ${ }^{2}$, Center for Islamic Philanthropy and Sicial Finance ${ }^{3}$
}

\begin{abstract}
Tahfiz education is one of the popular streams of education in Malaysia and well accepted by Muslim community. Originally the education is being offered in "pondok", a traditional religious school. Developing through times, it is now also being offered in tahfiz centers as well as in modern tahfiz institutions. These entities specialize in producing tahfiz graduates who can memorize and recite the whole Al-Quran and more than $91 \%$ of them are privately owned. The applicability of good governance and accountability measures is indeed highly desirable in these Islamic entities as it deals with the responsibility in fulfilling sacred religious obligation. Though the number of tahfiz education providers (TEP) has grown up tremendously from only 58 in 1999 to 278 in 2011, literatures on governance and accountability of TEP are still lacking as the areas are rarely examined directly. The lacking may lead to unfavorable inferences that TEP are behaving in the manners contrary to the interest of the stakeholders. An ideally accountable governance of tahfiz centers will gain trust from parents and various stakeholders and will indicate the achievement in fulfilling one of the objective of Maqasid Shariah to preserve and promote the religious faith through preserving the memorization and knowledge of Al Quran (the primary source of Islamic Law) by the huffaz. The objective of this research is to investigate external governance mechanism and the accountability of Tahfiz centers as viewed by religious regulatory bodies. A qualitative research approach is undertaken by interviewing representatives from selected State Islamic Religious Councils, State Islamic Foundation and National Religious Departments in Malaysia. Using thematic analysis, findings of this study revealed that there are two-tier governance infrastructures of tahfiz institutions in Malaysia. However, the enforcement of the governance structure is still at infancy level. The accountability frameworks of TEP management divulged in four dimensions; ultimate upwards, upward, parallel and downwards in organizing, teaching and learning, and compliance activities and legal requirements. The accountability can be measured using five accountability mechanisms namely report and disclosure statements, performance assessment and evaluations, participation, self-regulation, and social audit.
\end{abstract}

Keywords: Tahfiz, Accountability, Governance Mechanism, Islamic 


\section{INTRODUCTION}

\section{An Overview of Governance and Accountability of Tahfiz Institutions in Malaysian: Religious Councils Perspective}

Tahfiz schools have become avenues for Islamic education focusing on teaching students to memorize and recite the whole Al-Quran. The recorded number of centers offering the stream is mushrooming since the years 2000 with majority are privately owned centers (Bani, Katan, Mohd Noor \& Abdul Fatah, 2014). The Tahfiz school stream is also supported by The Ministry of Education through its commitment in implementing the Ulul Albab Tahfiz Model (TMUA) pioneer project in national religious schools (SMKA) and fully residential schools (Ministry of Education, 2016). Apparently there are 577 tahfiz centers in Malaysia; twenty (20) are state government schools, ten (10) tahfiz colleges and 547 are privately owned (JAKIM, 2016). This data provides evidences on parents' inclination in sending their children to tahfiz schools operated by either Ministry of Education (MOE), states or private entities.

The privately owned centers may be set up by an individual, public or private entities. As such they have different governance practices according to the founders' norms. Besides differences in the organizational structure, the centers may also have different curriculum. In general, there are two distinct stream; solely tahfiz education of fully Quranic teaching, and an integration of Quranic teaching and academics. A privately owned center may adopt any curriculum or teaching methods (Hashim, 2015). Due to these differences, there is a dire need of an efficient and standardize corporate governance that would result in systematic education accountability system. The education accountability has to comply with regulations, adhere to professional norms and results driven (Anderson, 2005). With the aim of understanding their complex structure, this study provides an overview of the external governance mechanism and accountability of these tahfiz centers from the regulatory bodies' perspective. Data were collected through several interviews with representatives from selected State Islamic Religious Councils, State Islamic Foundation and National Religious Department in Malaysia.

\section{The Development of Tahfiz Education in Malaysia}

Tahfiz education were initially conducted in "pondok", a traditional religious school. Then in 1966, tahfiz was institutionalized by the government when Tunku Abdul Rahman Al-Haj Prince, first Prime Minister of Malaysia, announced the aspiration to set up an Institute for the Study of the Quran in Malaysia. Started on March 1, 1966, Ma'ahad Tahfiz Quran wal Qiraat was set up and tahfiz classes were carried out at National Mosque Lecture Hall with eight pioneering students selected from various states in Malaysia. Efforts to establish Ma'ahad Tahfiz were made to preserve and promote the religious faith among Muslims. Since then tahfiz centers are opened in every states of Malaysia. In addition, tahfiz centers are also set up by private entities. The main objective of establishing tahfiz center is to produce tahfiz graduate who are valuable human capital needed for the development of the nation (Azmil, Abd. Halim, \& Misnan,2013).

In terms of the employability of tahfiz graduates on 16 April 1983, the certificate of eligibility produced by Darul Quran was recognized by the Public Service as equivalent to diploma from MARA Institute of Technology (now known as UiTM). This recognition enables Darul Quran graduates to be accepted as civil servants. Darul Quran graduates are also recognized by local and overseas universities where they can further their studies in any field of their choice. As such, tahfiz graduates graduates are equipped with both religious knowledge and professional expertise. 


\section{Corporate Governance}

Corporate Governance (CG) is a process of managing, directing, controlling, regulating, be in charge, planning and conducting affairs of an institution. In Arabic term Howkomat al Sharikat (حوكمةالثركات) literally means the governance of companies (Adwam, World Bank Group 2013). In Al Quran it is termed as Tadbir (نَبْبِ) (Al Burey, 1985). It refers to rational act of examining the consequence (s) of an affair so that a creditable result may be worked out and thus obtained.

The CG of any Islamic institution needs to escalate the stakeholders' relations in the systems and processes. Managers are required to act in a responsible manner in all areas of their activities they are accounted for. Efficient governance will undertake responsible activities, policies or programs to discharge accountability to various stakeholders so as to maximize the institution performance and the delivery outcome. On top of that it is to ensure that the operations conform to requirement of the law, regulations, standards and community expectation on accountability, transparency, justice and Theoretically, this resembles the application of stakeholder theory (Iqbal and Mirakhor, 2004; Hasan, 2008; Hasan and Harahap, 2010; Bani, 2014). The theory specifies that decision makers utilize resources efficiently, to manage them in the best interest of their principal stakeholders and to maintain good relationship between different stakeholders (Grais and Pellegrini, 2006). Indirectly, CG also covers decision-making activities; who make the decision on $\mathrm{CG}$, who will benefit from $\mathrm{CG}$ and what resources to use to materialize CG (Lewis, 2005).

Philosophically, efficient governance primarily needs to ensure efficient relationship with the ultimate stakeholder that is the resource owner (Allah) through compliance of Shari'ah. The Tawhidic paradigm (Unity of God) conceptually provides illustrations of the link between the spirit of Tawhid with all management functions (planning, organization, leading, and controlling) and ensures harmony between (Al-Akhirah - the Hereafter) and the worldly (Al Duniya). The mission and objectives will be achieved through continuous enforcement in promoting goodness (amr bil ma"aruf) and prevention of evil (wannaha anil munkar). Based on this paradigm, harmonized management approach, in accordance to the requirements of the religion (ad-din), is an important ingredient to achieve the objective of Shari'ah (Maqasid Shari'ah) of any Islamic institutions successfully. Commercially, an effective governance of tahfiz centres must be able to achieve its economic objective financial stability that will protect the economic interest of the shareholders and in return increase the value of the centre. Socially tahfiz centres must be efficient in protecting the interest of affected parties or entities (stakeholders) such as employees, the general community and environment surrounding the tahfiz center.

\section{Governance Framework of Tahfiz Schools in Malaysia}

Malaysia implements Public Sector Governance of school system since independence. The landscape of education system changed as a result of smart partnership which allows stakeholder active participation in the school system as a result of new initiatives introduced in 2006. The Education Development Master Plan - EDMP 2006-2010 (Ministry of Education, 2006) and National Key Result Areas (NKRA-one of the national development plan) implementation allows the existence of various types of schools, subjects and specializations. More private schools enter into the education sector, more private religious schools seek registration and vocational subjects in schools are given more emphasis. As a result this initiative provides more educational choices to parents and students. In line with this, statistics shows an increase in number of students attending religious schools offering tahfiz education (JAKIM, 2016) 
Tahfiz schools dealing with religious education activities falls under the category of not for profit sector. The framework of governance for Tahfiz schools is based on public sector governance best practices. Tahfiz schools operating under the supervision of MOE and state government have less autonomy and generally react to government initiatives enforced. Privately owned tahfiz schools have high autonomy as they lead the centers on their own and update the government on their policy and may receive many state initiatives. Effective governance of tahfiz schools is very important as effective and accountable governance will gain trust from parents and various stakeholders and achieve of the objective of Maqasid Shariah to preserve and promote the religious faith through preserving the memorization and knowledge of Al Quran (the primary source of Islamic Law) by the huffaz (Bani, Katan, Mohd Noor and Jaafar, 2016).

In Malaysia, tahfiz education is being offered in schools under MOE, schools under state supervision and private schools. Tahfiz schools may be named differently by the operators such as Mahaad, Tahfiz Center, Ulul Albab School and others. Tahfiz schools under MOE in general are under of MOE's governing authority. Private religious schools or centers offering the teaching of Al Quran together with national academic curriculum are also subject to MOE and religious council governing authority. Whilst, private tahfiz institutions or centers focusing on the teaching of Al Quran only and not registered with MOE are under the governance of the State Religious authority. As such there are two external governance mechanisms for tahfiz schools; MOE and State Religious Council (refer to Figure 1)

The external control mechanisms generally monitor the legal compliance and management adequacy of tahfiz schools or centers. The authority issues regulatory guidelines and suggest guidelines for best practices which work as boundaries to the operations. An efficient and good governance of tahfiz centers are expected to report their compliance status to external stakeholders. Though there are two external governance mechanisms directly regulating and controlling tahfiz schools or centers, this study limits the discussion on the mechanism from the state religious council perspectives. 


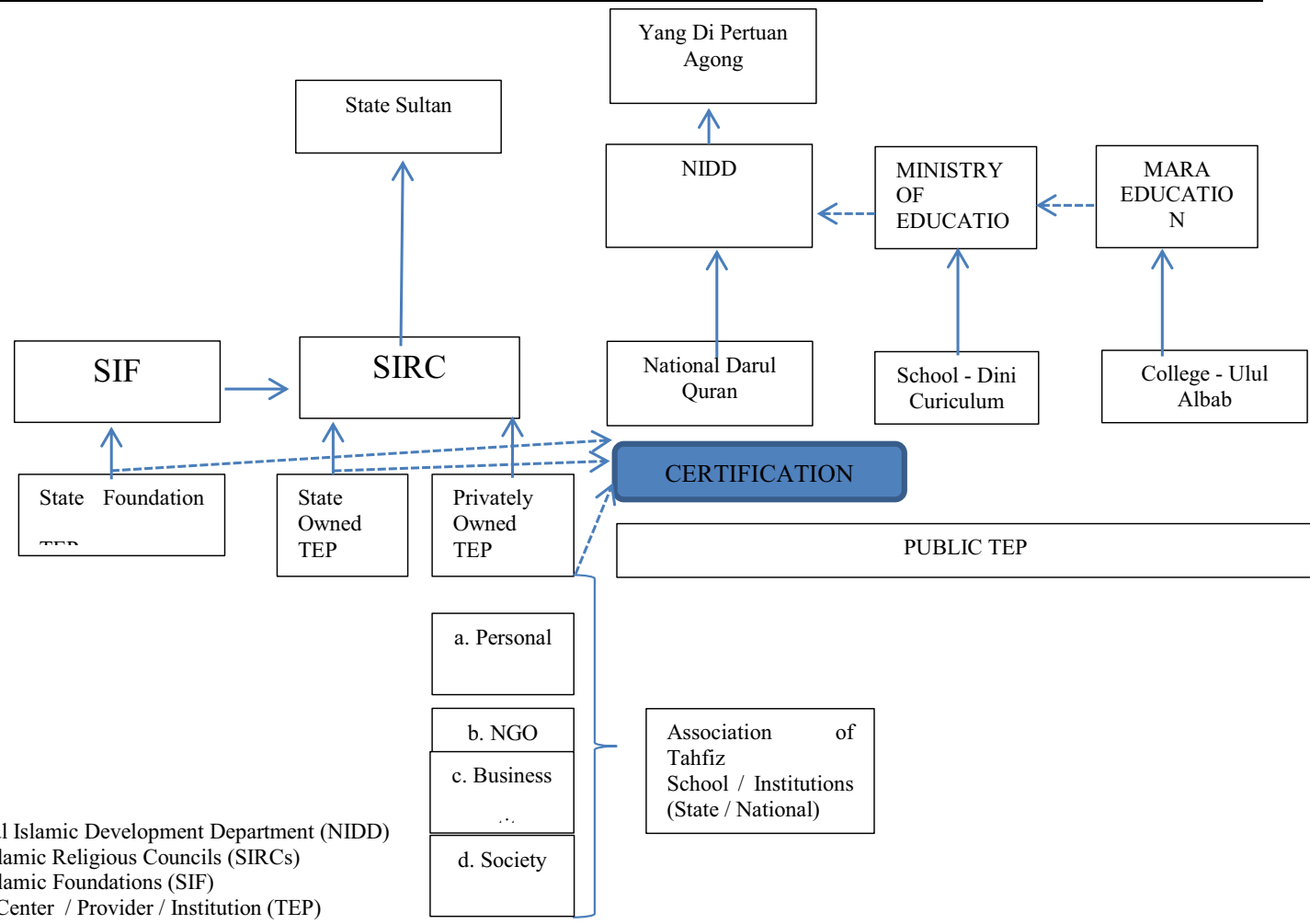

National Islamic Development Department (NIDD)

State Islamic Religious Councils (SIRCs)

State Islamic Foundations (SIF)

Tahfiz Center / Provider / Institution (TEP)

Figure 1: Governance Framework of Tahfiz Schools in Malaysia

\section{Regulatory Framework Of Tahfiz School Religious Council Perspective}

Private Tahfiz schools are categorized as Islamic religious school in Malaysia. As such these schools are subject to state regulatory enactment of Islamic religion according to the state where they are registered. The state is responsible in creating a regulatory framework as a mechanism to ensure that the objective of tahfiz schools is aligned with the goal of the sector and the regulation set able to influence the behavior of the players in the sector. Besides state enactment of legislation for the administration of Islamic religion, tahfiz schools are also enacted to State Enactment Controlling Islamic Religious Schools. These enactment acts as external governance mechanism in regulating tahfiz institution. Table 1.0 highlights regulatory framework of Tahfiz Schools in three different states. Relevant sections in the State enactments are being referred for discussion. 
Table 1: State Enactment applicable for Tahfiz institutions

\begin{tabular}{|c|c|c|}
\hline State No & State Enactment and Control & Content of Enactment \\
\hline \multirow[t]{9}{*}{ State 1} & State Enactment & Seksyen 108. Religious school. \\
\hline & Enactment No 72002 & Subject to the Control of Islamic Religious Schools Enactment 2002 \\
\hline & Section 108 & $\begin{array}{l}\text { [Enactment No. } 3 \text { of 2002] the Majlis shall have power to register } \\
\text { Islamic Religious schools in the State }\end{array}$ \\
\hline & & i. Introduction \\
\hline & Enactment Controlling & ii. Registrar/ Deputy Registrar \\
\hline & Islamic Religious Schools No & iii. Registration of religious schools \\
\hline & 3 of 2002 and Registration & iv. Board of Management \\
\hline & rules & v. Inspectors of Islamic Religious Schools \\
\hline & 2003 (Part i - iiv) & $\begin{array}{l}\text { vi. Inspection of Religious Schools by Registrar } \\
\text { vii. Miscellaneous }\end{array}$ \\
\hline \multirow[t]{7}{*}{ State 2} & State Enactment & Subject to the control of Islamic Religious School Enactment 1988 \\
\hline & Section 120 & $\begin{array}{l}\text { Enactment No } 2 \text { the Majlis shall have power to register Islamic } \\
\text { Religious School in the State }\end{array}$ \\
\hline & Enactment Controlling & i. Introduction \\
\hline & Islamic Religious Schools & ii. Registrar/ Deputy Registrar \\
\hline & Enactment 21988 & iii. Registration of religious schools \\
\hline & (Part i- vi) & iv. Board of Management \\
\hline & & v. Inspectors of Islamic Religious Schools \\
\hline \multirow[t]{3}{*}{ State 3} & State enactment & Section $96(1)$ \\
\hline & Section $96(1)$ & The Majlis shall have power to registerand control Islamic Religious \\
\hline & Section $96(2)$ & $\begin{array}{l}\text { School and Islamic education institution in the State and any related } \\
\text { matters to it. }\end{array}$ \\
\hline
\end{tabular}

Section 96(2)

The Majlis can exempt any Islamic religious school or institutions from registration and monitoring

No specific enactment on controlling the Islamic religious school or institutions

\section{Table 2: The content of States' enactment controlling state religious schools in State 1 and} State 2 .
Part i. As Preliminary part this section provides interpretations of term and terminology used in the enactment.
Part ii. Explains procedures in appointing the registrars etc. and the power and duty of registrar
Part iii.
Explain procedures in registering the religious school, application to establish religious school, registration and revocation of registration, procedure in appealing for registration, prohibition to
Part iv. advertise religious school and prohibition in change of address of premise of religious school.
Explaining the instruments in establishing board management and its membership,
Part v. qualification of the members of the board, board duties and responsibilities, and power of board
Part vi.
Explain the appointment and right of the inspector to inspect school and the right of Majlis to authorize any person to inspect school
(Only in State 1) Explain the provision which allow registrar to inspect school and the power of the registrar on inspection, procedure in inspection, power to close unregistered religious school, power to investigate and power to enter school without warrant.

Part iiv (State 1) and Part vi (State 2)

The last part in the enactment on miscellaneous items provide the power of Advisory Board to give assistance to Majlis, the right of Majlis to give exemption for all provisions of the enactments except for registration, conviction for obstruction to registrar etc in carrying out their duties and responsibilities, the liability of the director, manager, secretary or officers for offence made by the corporate body, general penalty of an offence, jurisdiction to try offences, Director's written consent in the institution of prosecution, protection against suits and legal proceedings, the position of officers as public servant, documentation and regulation for the Islamic school operations. 
In different to State 1 and State 2, State 3 did not have specific enactment in controlling Islamic religious schools. As such, in the State 3 Tahfiz centers administration uses general law as stated in section 96 (1) and 96(2). In that, the state enactment may exempt the Islamic religious school from registration and monitored by the Majlis. State 1 and State 2 have similarities in their Enactment Controlling Islamic Religious Schools except for an additional section elaborating the inspection of Religious Schools by Registrar in State 1. Finding from these comparisons may deduce that the legislations and regulations for tahfiz institution in Malaysia are available in the state enactment but they have yet to be standardize and enforced nationally. Standardized regulations is needed so that evaluation on the compliance to legislations, rules and regulations and assessment of the sector goals achievement is align to religious and society expectations.

\section{Governance Players in Tahfiz School and Their Accountability}

Several governance players in Islamic school are highlighted in the enactment. Each player has their own accountability in managing, controlling and monitoring Islamic school operation. Applying the general principles in the enactment for Religious schools the key players in tahfiz schools are Yang Dipertuan Agong, Directors and officers in National Religious Department, Director and officers in Islamic studies at Ministry of Education (MOE), Registrar comprised of Directors and officers appointed at State religious department, board of management also known as board of trustee, school inspectors and teachers. These players have various accountabilities (acknowledgement of responsibilities) for policies, decisions and actions within the ambit of their role in the tahfiz schools. Based on the findings from interviews and review of enactments controlling religious schools in selected states, this study suggests the uniform key players in tahfiz school governance and their accountability as in Table 2.0.

Table 3: Key Players and Governance Accountability of Tahfiz Schools

\begin{tabular}{|c|c|c|c|}
\hline & Players & Structure & Accountability \\
\hline 1 & Yang Di Pertuan Agong & $\begin{array}{l}\text { Legislative } \\
\text { power for } \\
\text { authorization and } \\
\text { delegation }\end{array}$ & $\begin{array}{l}\text { a) Notify in the gazette the } \\
\text { effective date of the enactment } \\
\text { b) Approved the appointment of } \\
\text { registrar and deputy registrars } \\
\text { c) Make regulation (with the advice of Majlis) to } \\
\text { ensure the provision of the enactment are carried out } \\
\text { into effect }\end{array}$ \\
\hline 2 & National Religious Department & $\begin{array}{l}\text { Director, } \\
\text { Assistant } \\
\text { Director and } \\
\text { officers at } \\
\text { National and } \\
\text { State department }\end{array}$ & $\begin{array}{l}\text { a) Undertake national or state level } \\
\text { monitoring activities } \\
\text { b) Distributes the allocated fund } \\
\text { - Zakat } \\
\text { - Ministry of Education } \\
\text { (Private Education sector funds) }\end{array}$ \\
\hline 3 & Ministry of Education & $\begin{array}{l}\text { National } \\
\text { Education } \\
\text { Department - } \\
\text { Islamic Studies }\end{array}$ & $\begin{array}{l}\text { Undertake national level monitoring for Tahfiz schools } \\
\text { under MOE }\end{array}$ \\
\hline 4 & $\begin{array}{l}\text { Registrar at State religious } \\
\text { department (Majlis) }\end{array}$ & $\begin{array}{l}\text { Registrar } \\
\text { Deputy Registrar } \\
\text { Officer }\end{array}$ & $\begin{array}{l}\text { a) ensure tahfiz schools are properly administered } \\
\text { b) Ensure that the state of affairs of Tahfiz schools } \\
\text { are informed to Majlis } \\
\text { c) Keep register of all registered tahfiz school (name, } \\
\text { address, members of the board, school curriculum } \\
\text { and information deemed necessary by registrar } \\
\text { d) Direct, control make } \\
\text { delegation to assistant registrar, } \\
\text { revoke delegation } \\
\text { e) Inspect tahfiz schools } \\
\text { f) Inspect unregistered premises } \\
\text { g) Seize any materials to furnish }\end{array}$ \\
\hline
\end{tabular}




\section{5}

Board of
Management

Employed by MOE or tahfiz school evidence of offence against

enactment

h) Close unregistered Tahfiz Schools

i) Investigate into commission of any offence under enactment

j) To enter premises without warrant on reasonable ground

Trustee for the school

a) Acquire / purchase assets

b) To borrow from time to time

c) To make arrangement with the state or federal government
Responsibility

a) Maintain the school

b) Comply with the direction of registrar

c) Maintain book of record

- Teacher and staff

- $\quad$ Students, age and sex

- Financial sources of the school

- Curriculum of the school

- $\quad$ Other information required by registrar

d) Administer school fund

e) Submit report to registrar

f) Comply curriculum made by Majlis

a) make school inspection

- Teaching the permitted curriculum

- Textbook used

- Teachers employed

- Compliance on enactment

b) conduct investigation on any matters as may be authorized by the Registrar

c) make inspection of school account

d) report irregular matters to registrar

e) perform other duties as directed by Registrar

a) Qualified and trained teacher

b) Jointly liable on the offence of the Tahfiz school

c) Teaching and learning of Tahfiz school students

d) Adhere to teaching curriculum set by SIRC

To protect the interest of Private Tahfiz schools in Malaysia (especially the registered member)
Association of Private Tahfiz Schools / Institutions
State

Association and National Association

In summary, governance of Tahfiz institution has two tier governance infrastructure; state and tahfiz school infrastructure. At state level, the state management will issue rules and regulations binding to all Tahfiz schools, advice the board management and monitor the compliance. Tahfiz governance players who are involved in these activities are Yang Di Pertuan Agong, Directors, Deputy Directors and officers at National Islamic Religious Department; and Registrar, Deputy Registrar and officers at State National Islamic Religious Department ; who 
are accountable to undertake various responsibility as specified in Table 2.0 above. At Tahfiz School level, board management and teachers are trusted to have standard procedures in ensuring the compliance to the state rules and regulations. In attesting that the enactment, rules and regulation issued by the state authority are complied, an audit work will be undertaken by the school inspector. As such the inspector represents the third governance mechanism i.e the independent auditors to tahfiz schools. The detail accountabilities of this player are specified in the above Table 3.0.

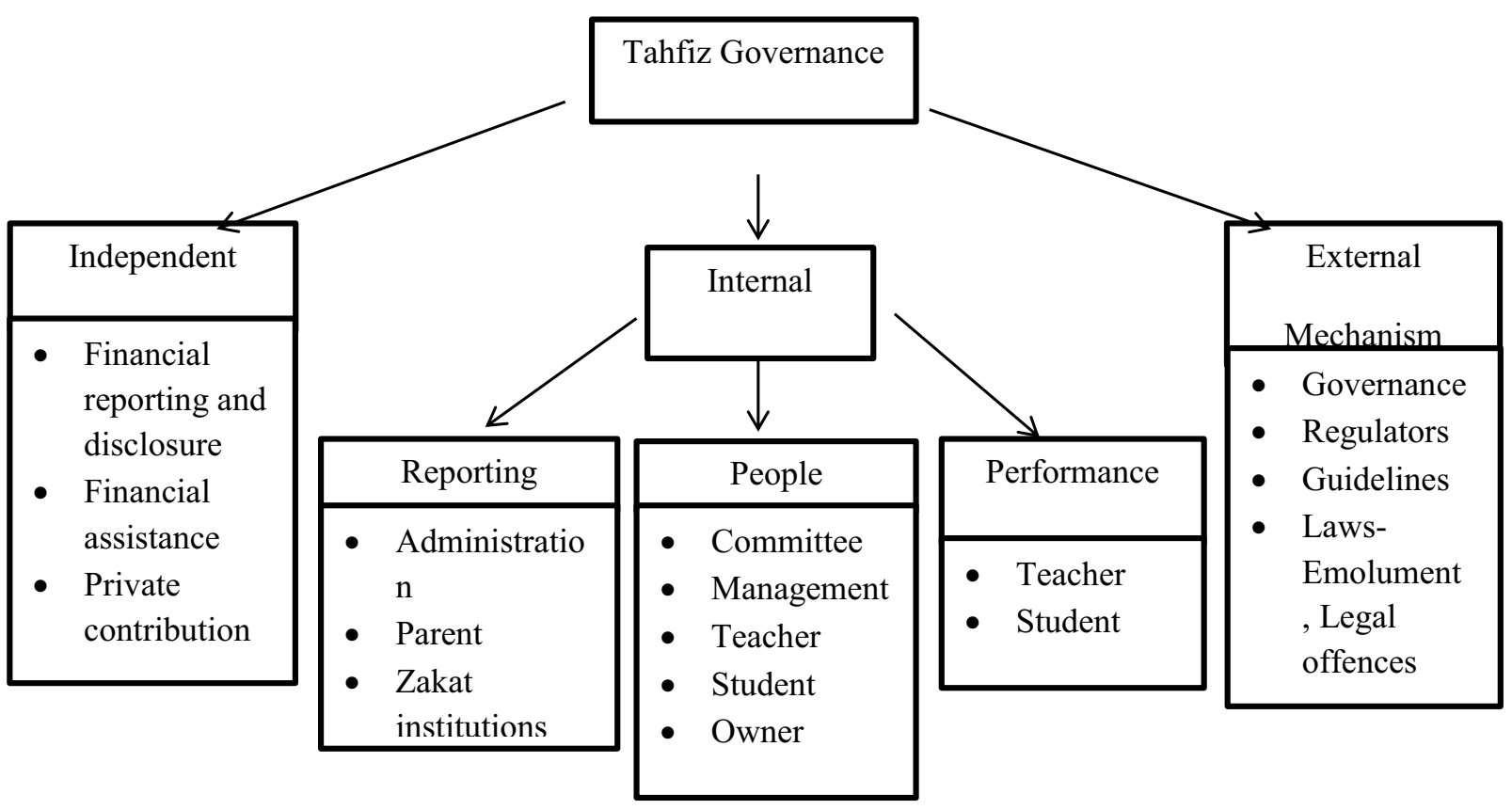

\section{Tahfiz Governance Mechanism}

As a summary to accountability issue in Tahfiz education, key Tahfiz schools governance players are accountable to the achievement of Maqasid Shariah in the aim to protect Ad-din particularly through producing tahfiz graduates with the capability of preserving the memory on the main source of Shariah (Al Quran) and the teaching. Based on this objective, accountability mechanism by Ebrahim (2010) is broadening by the inclusion of ultimate accountability. Ultimate accountability is the accountability of an individual man to perfect himself / herself to Allah derived from the concept of khalifah (vicegerence) in which man become a trustee of Allah resources.

The management of TEP is accountable to other stakeholders such as nature and Universe, donors, regulators, human resources, students, parents and society. According to Llyod (2005) these can be further categorized as upwards accountability, downwards accountability and parallel accountability. The upward accountability refers to accountability / responsibilities to bodies that give them financial aid and legal base such as donors, foundations and governments. In the context of Tahfiz schools, upward accountability is the accountability to the aid giver such as Ministry of Education, Zakat institutions, and donors who provide assistance to the TEP's operations both in financial and non-financial form as well as State and National Religious regulators bodies who perform oversight function. The horizontal accountability refers to the accountability between Tahfiz schools and the employees, peers or the management of TEP who directly involved in the Tahfiz schools day to day operations. The 
downwards accountability referred to collective accountability of Tahfiz schools to their beneficiaries whom they provide their services in perfecting the quality of tahfiz graduates, such as fulfilling the parents aspirations and serving the surrounding communities.

The summary of the proposed graphical accountability line suitable for tahfiz schools dealing with ultimate upwards, upward, parallel and downwards is captured in figure 3 below Bani, Katan,Jaafar, Mohd Noor,(2015) . Kementerian Pengajian Tinggi

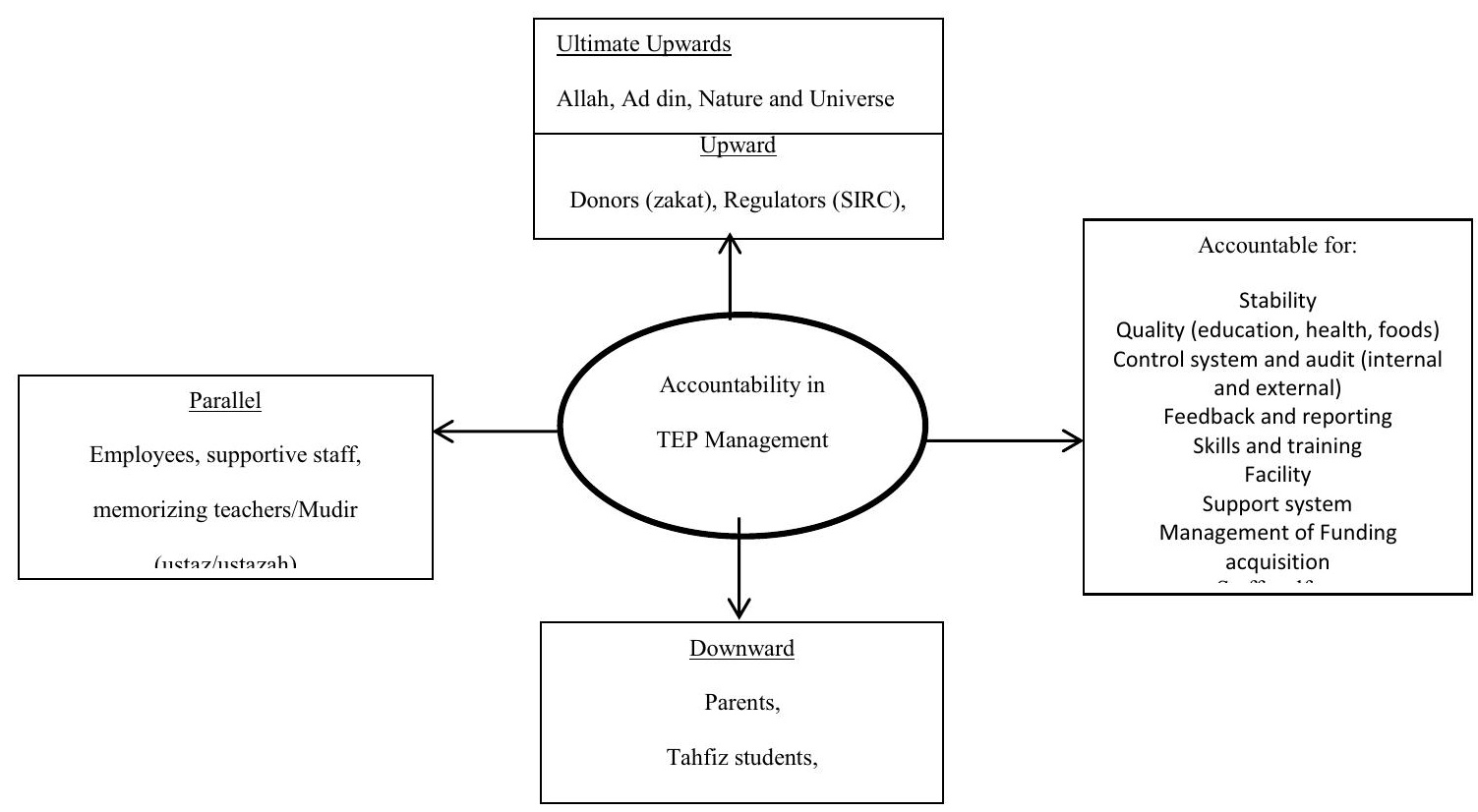

Figure 3: Accountability in Tahfiz Education Providers (TEP) Management

\section{DIRECTION OF FUTURE RESEARCH}

Tahfiz school governance mechanism research is still at infancy level. While main stream research on tahfiz education revolves around teaching and learning method (Ashraf, Ab Halim Tamuri, Kamarulzaman \& Nurul Hudaa,2013; Azmil, Ab Tamuri (2012), memorization technique (Abdul Hafiz \& Hasimah, 2004; ) and rules and students (Norlizah, Fathiyah, Ahmad Fauzi, Lukman \& Wan Marzuki , 2015) high expectation has been placed by the Muslim community on Tahfiz performance. Hence, future research may be directed to evaluate the performance of Tahfiz Schools, the compliance to enactment, ethical principles of Private Tahfiz school management and accountability of Private Tahfiz Education Providers as well as fund management. It is expected that the best practice of managing private tahfizs can be unveiled and knowledge will help other private tahfiz schools calrify their role systematically to uplift their performance. 


\section{REFERENCES}

Abdullah, A. H., Salamon, H., Suratman, A. S., Noor, S. S. M., Jasmi, K. A., \& Samat, A. B. (2005). Sistem Pembelajaran Dan Kaedah Hafazan Al-Qur' Yang Efektif: Satu Kajian Ustaz Abdul Hafiz Bin Haji Abdullah Ustaz Kamarul Azmi Bin Jasmi.

Azmil, H., Abd. Halim, T., \& Misnan, J. (2013). Latar Belakang Guru Tahfiz Dan Amalan Kaedah. Journal Of Islamic Education, 1(1), 28-39.

Administration of the religion of Islam State of .....2003, Percetakan Nasional Malaysia Berhad, Kuala Lumpur

Bani, H., Katan, M., Noor, A. H. M., \& Fatah, M. M. A. (2014). Applying Stakeholder Approach In Developing Accountability Indicators, (September) iCARE Proceeding

Bani, Katan,Jaafar, Mohd Noor,( 2015), Tahfiz Education Provider Accountability Model . (FRGS/1/2015/SS01/UITM/02/9), Kementerian Pengajian Tinggi Malaysia

Ebrahim, A. (2003). Accountability In Practice : Mechanisms for NGOs, 31(5), 813-829.

Enactment Controlling Islamic Religious Schools No 3 of 2002 and Registration rules 2003 Control of Islamic Religious Schools, Percetakan Nasional Malaysia Berhad, Kuala Lumpur

Guskey, T. R. (2007). Leadership in the age of accountability. Educational Horizons, 29-34.

Henard, F \& Mitterle, A. (2012), Governance and quality guidelines in Higher Education. A Review of Governance Arrangements and Quality Assurance Guidelines, Organization of for Economic Corporation and Development (OECD)

Hashim, A. (2015). Correlation between Strategy of Tahfiz Learning Styles and Students Performance in Al-Qur'an Memorization (Hifz). Mediterranean Journal of Social Sciences, $6(2), 85-92$.

Hassan, N. C., Fakhruddin, F. M., Fauzi, A., Ayub, M., \& Mutalib, L. A. (2015). Tahfiz Schools Entry Requirement and Characteristics of Tahfiz Students, I(3), 234-241.

Hanushek, E. A., \& Raymond, M. E. (2004). The Effect Of School Accountability Systems On The Level And Distribution Of Student Achievement, (May 2004), 406-415.

Jabatan Kemajuan Islam Malaysia (2016), Data Masjid, Surau, Kafa dan Sekolah Agama Tahun 2016, Bahagian Kemajuan Islam

Kementerian Pengajian Tinggi, (2015) Tahfiz Education Provider Accountability Model. KPT, FRGS/1/2015/SS01/UITM/02/9)

Jensen, C., \& Meckling, H. (1976). Theory Of The Firm : Managerial Behavior, Agency Costs And Ownership Structure I 3, 305-360.

Kai, J. (2009). A Critical Analysis of Accountability in Higher Education. Chinese Education 
\& Society, 42(2), 39-51.

Lloyd, R. (2005). The Role of NGO Self-Regulation in Increasing Stakeholder Accountability, (210180), 1-15.

Lessing, J.,Morrison, D.\& Nicolae (2012)"Educational institutions, corporate governance and not for profit" Corporate Governance e-Journal, 1-22,ISSN 1836 -1110

Ministry of Education (2016). Surat Pekeliling Iktisas KPM Bil 12016 Perlaksanaan Tahfiz Model Ulul Albab di Sekolah Menengah Kementerian Pendidikan Malaysia.

http://www.moe.gov.my/v/pekeliling-ikhtisas-view?id=1094

Nakpodia, E. D., \& Okiemute, A. R. (2011). Teacher's accountability in Nigerian education system: Perceptions of teachers and administrators in Delta State. International NGO Journal, 6(7), 152-158. doi: 10.5897/ngoj11.009

Norlizah , Fathiyah, Lukman \& Wan Marzuki (2015), Tahfiz Schools Entry Requirement and Characteristics of Tahfiz Students, International E-Journal of Advances in Education, Vol.1, Issue 3, December

Samah, R. A. (2016, January). More Maahad Tahfiz schools should be built around the country:Zahid. New Strait Times. Retrieved from http://www.nst.com.my/news/2016

Shuaib, F. S. (2008). Strengthening Administrative Institutions Of Islamic Law In Malaysia:, $16,443-464$.

Siraj, S. A. (2012). An Empirical Investigation Into The Accounting, Accountability And Effectiveness Of Waqf Management In The State Islamic Religious Councils ( Sircs ).

Urbanski, A. (1998). Teacher Professionalism and Teacher Accountability: Toward a more Genuine Teaching Profession. Educational Policy, 12(4), 449-457. doi:

10.1177/0895904898012004006 